\title{
Risk factors for computer visual syndrome (CVS) among operators of two call centers in São Paulo, Brazil
}

\author{
Eduardo Costa Sa ${ }^{\mathrm{a}, \mathrm{c}}$, Mario Ferreira Junior ${ }^{\mathrm{b}}$, Lys Esther Rocha ${ }^{\mathrm{a}}$ \\ a Universidade de São Paulo, Faculdade de Medicina, Departamento de Medicina Legal, Ética Médica, Medicina \\ Social e do Trabalho, LIM-40, SP, Brazil. \\ b Universidade de São Paulo, Faculdade de Medicina, São Paulo, SP, Brazil. \\ c Universidade de São Paulo, Faculdade de Saúde Pública, São Paulo, SP, Brazil.
}

\begin{abstract}
The aims of this study were to investigate work conditions, to estimate the prevalence and to describe risk factors associated with Computer Vision Syndrome among two call centers' operators in São Paulo $(n=476)$. The methods include a quantitative cross-sectional observational study and an ergonomic work analysis, using work observation, interviews and questionnaires. The case definition was the presence of one or more specific ocular symptoms answered as always, often or sometimes. The multiple logistic regression model, were created using the stepwise forward likelihood method and remained the variables with levels below $5 \%(\mathrm{p}<0.05)$. The operators were mainly female and young (from 15 to 24 years old). The call center was opened 24 hours and the operators weekly hours were 36 hours with break time from 21 to 35 minutes per day. The symptoms reported were eye fatigue $(73.9 \%)$, "weight" in the eyes $(68.2 \%)$, "burning" eyes $(54.6 \%)$, tearing $(43.9 \%)$ and weakening of vision (43.5\%). The prevalence of Computer Vision Syndrome was 54.6\%. Associations verified were: being female (OR 2.6, 95\% CI 1.6 to 4.1), lack of recognition at work (OR 1.4, 95\% CI 1.1 to 1.8), organization of work in call center (OR 1.4, 95\% CI 1.1 to 1.7 ) and high demand at work (OR 1.1, 95\% CI 1.0 to 1.3 ). The organization and psychosocial factors at work should be included in prevention programs of visual syndrome among call centers' operators.
\end{abstract}

Keywords: Call center; Visual fatigue; Risk factors; Occupational health; Computer visual syndrome

\section{Introduction}

Visual fatigue is an eye disorder that is studied because of its high prevalence and its increase in some activities $[12,17-18,20,25$, 26] including the professionals who work with computer.

The occurrence of visual fatigue in professionals who use computers was first described in 1982 by Elias and Cail [21] whom considered it as a functional disorder, by excessive and prolonged contractions of the ciliary muscles of the eye, in order to obtain a fine focus objects. Blehm et al. [5], have defined the visual fatigue associated with computer work as Computer Vision Syndrome (CVS) that can be characterized by the presence of one or more eye symptoms (visual fatigue, eye fatigue, burning sensation, eye irritation, "redness", "blurred vision" and "dry eyes").

The potential pathophysiological mechanisms of CVS were grouped by Blehm et al. [5] in three clusters of symptoms: eye disorders: local pain, burning sensation, feeling of "burning", changes in blinking frequency, excessive tearing and "dry eye"; visual disturbances: photosensitivity, difficulty focusing (blurred vision), double vision, persistent abnormal image after-image and instability in its optical and spatial definition; general disorders: headaches, migraines, back pain and/or neck pain, muscle spasms in the regions of the neck and shoulders, the latter requires the presence of other ocular symptoms.

The causes of CVS have been categorized by Blehm et al. [5] on intrinsic and extrinsic

* Eduardo Costa Sá-: Faculdade de Medicina da USP, Instituto Oscar Freire. Av. Dr. Arnaldo, 455 - São Paulo, SP, Brazil - CEP: 01246-000 - Tel. 55 11 3061-8419, e-mail: eduardocs6@gmail.com 
environmental and extrinsic eye. The intrinsic factors are mainly caused by the mechanism of eye accommodation. Two examples are of the refractive errors not properly corrected, or when there is the presence of ocular-motor group of phorias.

Extrinsic environmental factors include the lighting environmental conditions. Lighting in the workplace can be natural or artificial the latter consist of electric lamps, which can be fluorescent, incandescent, mercury or sodium [8].

Blehm et al. [5] considered as extrinsic eye factors: the decrease in the rate of flashing/blinking; the increase of exposure of the ocular surface; the use of contact lenses or medication; the presence of systemic or external eye diseases.

Piccoli [2] describes that the changes in work processes and the increase of the computers' use cause a need for an efficient visual systems. The association between visual disorders and psychosocial work factors is suggested by the idea that visual disturbances are related to the intensity and duration of visual requirements and to the work situation perceived by the employee and to the pathophysiological characteristics of the visual system of each individual [2].

The International Labour Organization [11] defines the psychosocial factors as the interaction of workers' perceptions and experience with aspects related to the work conditions and also the social system.

To explain the work stress and the impact on workers' health, the study adopted the model of Karasek and Theorell [22], known as the demand-control model that assumes that occupational stress can lead to diseases. According to Araujo [24], the model provides, from a combination of different levels of control and demand, four basic types of experiences at work: high-strain job (work situation characterized by high demand and low control), active work (situation of high demand and high control), passive jobs (low demand and low control) and low strain (combining low demand and high control).

The studies about the impact of work and vision have grown in the last years $[2,6,12$, 18]. One consequence was the creation of a specific scientific committee at the International Commission on Occupational Health defined as International Scientific Committee on Work and Vision. The document prepared by this committee concluded that the work-related eye disorders are multifactorial and may be associated with work activity, environmental conditions and ophtalmic individual characteristics [2]. According to the committee, the advance of research in this area should provide workers with better visual conditions in the workplace, resulting in a better quality at work and higher productivity.

One professional that should be studied is the call center operator worker. The use of computers is consistently one of the characteristics of call center, which can be defined as an organizational structure that includes jobs for customer service through the use of a computer terminal and a telephone [13]. For Read [3], from the standpoint of health, the environment of call centers is considered medium to high risk and one health effect is the visual fatigue of workers.

According to Raab Glina and Rocha [7], the psychosocial aspects identified in the working conditions of the call center operators included: high quantitative and qualitative demands, with significant emotional, cognitive and physical loads, lack of control over work, the high volume of information to be dealt with, contradictory demands from the enterprise, based on a small average work time for each call and high quality services, and difficult in the relationships with customers.

The aims of this study are: investigate the working conditions and organization in call centers; to evaluate the prevalence of CVS, among call centers' operators and describe risk factors associated to work conditions and sociodemographic characteristics in two call centers of São Paulo - Brazil.

\section{Methods}

This study is a cross-sectional observational study and an ergonomic work analysis that were conducted in two call centers. It was approved by Ethics Committee from Medicine School and Public Health School of University of São Paulo. All participants were informed of the objectives and participated voluntarily in this study.

\section{Study population}

One call center was a central administrator of health plans (HPC), with 134 workers and the other was a booking center of an airline (ATC), with 397 workers. In total 476 questionnaires were filled: 125 of HPC and 351 of ATC. The reasons why the professionals did not participate in the study were: vacations, on maternity leave and absences. There were two cases of refusal.

Ergonomic work analysis 
An ergonomic work analysis was conducted according to methodology developed by Guerin et al. [9]. This method is composed of five steps: analysis of the demand (consists of discussing and clarifying the problems to be solved); task analysis (everything that defines the work of each one, in a given structure); activity analysis (systemic analysis of the work behaviors); validation; diagnose and recommendations. There were a total of 26 technical visits to the call centers and each one had an average of 4 hours.

\section{Questionnaire}

In this project a structured questionnaire was applied, including questions about visual complaints, adapted by Elias and Cail [21]. Information collected were: socio-demographic, lifestyle habits, occupational history, work situation (conditions and work organization) factors of satisfaction and factors of fatigue or discomfort at work, psychosocial aspects and work-related health effects.

The factors of satisfaction and factors of fatigue or discomfort were based on the results of ergonomic work analysis.

The categorization of responses was composed by five alternatives: never, rarely, sometimes, often and always or great, good, fair, poor and bad.

The questionnaires were self-applied in different work schedule, and were filled during working times in a room near their activities. The mean time for filling out the forms was 40 minutes.

\section{Data analysis}

Data from observations and interviews were analyzed. Data from ergonomic work analysis provided a description of the activity of call center operators of each enterprise.

The distribution of all variables was described and also the distribution according to the presence of CVS with the absolute and relative frequencies (count and percentage). For each variable it was use the chi-square tests likelihood ratio and Fisher exact tests (bivariate tests) to define the level of association (p).

The eye symptoms were studied based on the division between visual and ocular symptoms described by Blehm et al. [5]. Oculars symptoms were: "burning" eyes and tearing. The visual symptoms were: eye fatigue, weight in eyes and weakened vision. In this study CVS were considered when operators answered the presence of ocular symptoms as always, often or sometimes. Operators who reported visual disturbances were excluded because these symptoms were more general and related to the mechanism of accommodation.

A factor analysis was carried out to reduce the number of variables related with factors of fatigue or discomfort at work. The application of factor analysis allowed us to obtain factor scores to be used in the second phase, which corresponds to the application of multiple linear regression analysis. For this analysis, we used the program "Statistical Package for the Social Sciences" - SPSS - with sub-FACTOR, the factors extracted by the method of principal components with eigenvalues greater than 1.0.

Based on the Karasek and Theorell [22] model, the sum of the issues of requirements/ demand at work with the higher the greater risk to stress. The sums of the issues of decision making authority, the discriminations tasks, the job security and the support from superiors and colleagues with the lower sum the greater risk to stress.

The multiple logistic regression model was created using the forward stepwise likelihood ratio method with the variables with significance levels in the bivariate tests below $20 \%(p<0.20)$. The variables that remained in the final model were the ones with statistical significance levels below 5\% $(\mathrm{p}<0.05)$.

\section{Results}

The work of call centers' operators

The call center of the Health Plan Company was designed to provide information and guidance to 612.000 users. As well as, grant authorizations for medical and laboratorial procedures. The call center of the Air Transport Company had as its main activity booking and receiving calls from passengers and travel agencies, providing information on pricing, alternative routes and flight schedules, and making ticket reservations.

The call center workers activity of both centers consists on after establishing an early phone conversation with the client, search for information on computer screens and provide data and sometimes to enter data according to the reasons for the call. Workers remained in static setting posture $95 \%$ of the time.

In general, the operator had some guidance from the system to respond to customer issues. The complexity of the task was characterized by the diversity of clients and their needs, creating the search for consultation of documents, colleagues and supervisors, in order to fulfill the demand.

The call centers were opened 24 hours, including weekends and holidays, with four shifts: morning, afternoon, evening and night. 
The operators weekly hours were 36 hours, six hours each day. They generally did not performed over time. The break during each work day was from twenty one to thirty five minutes.

The operators cited as factors related to fatigue or discomfort at work: pressure queue (clients who are waiting for telephone service), small number of breaks, lack of prospects for career advancement, uncooperative users that lengthens the duration of the call, being "seen and treated" as a machine and lack of recognition by the company.

Table 1

Distribution of call centers' operators and prevalence of

CVS according to socio-demographic characteristics,

lifestyle habits, domestic work and occupational history

\begin{tabular}{|c|c|c|c|c|c|}
\hline \multirow[t]{2}{*}{ Characteristics } & \multicolumn{2}{|c|}{ Total } & \multicolumn{3}{|c|}{ Prevalence } \\
\hline & $N^{*}=476$ & $\%$ & $\mathbf{N}$ & $\%$ & $\mathbf{P}$ \\
\hline Gender & & & & & $<0.001$ \\
\hline Female & 353 & 74.8 & 214 & 61 & \\
\hline Male & 119 & 25.2 & 46 & 39 & \\
\hline Age (years) & & & & & 0.136 \\
\hline $15-24$ & 223 & 46.8 & 132 & 59 & \\
\hline $25-34$ & 167 & 35.1 & 87 & 52 & \\
\hline 35 or more & 86 & 18.1 & 41 & 48 & \\
\hline Educational Level & & & & & 0.340 \\
\hline High school & 113 & 23,7 & 55 & 49 & \\
\hline College incomplete & 216 & 45.4 & 121 & 56 & \\
\hline College complete & 147 & 30.9 & 84 & 57 & \\
\hline Marital Status & & & & & 0.888 \\
\hline Single & 337 & 70.8 & 185 & 55 & \\
\hline Married & 113 & 23.7 & 62 & 55 & \\
\hline Single/widowed & 26 & 5.5 & 13 & 50 & \\
\hline Smoking & & & & & 0.904 \\
\hline Never smoked & 309 & 64.9 & 171 & 55 & \\
\hline Stopped smoking & 52 & 1.9 & 28 & 54 & \\
\hline Regular smoker & 69 & 14.5 & 35 & 51 & \\
\hline Casual smoker & 46 & 9.7 & 26 & 57 & \\
\hline Alcohol intake & & & & & 0.164 \\
\hline Non drinker & 181 & 38.0 & 94 & 52 & \\
\hline Once a week & 196 & 41.2 & 117 & 60 & \\
\hline More than once a week & 99 & 20.8 & 49 & 49 & \\
\hline Physical activities & & & & & 0.197 \\
\hline Yes & 249 & 52.3 & 143 & 57 & \\
\hline No & 227 & 47.7 & 117 & 51 & \\
\hline Domestic work & & & & & 0.136 \\
\hline None & 302 & 63.4 & 160 & 53 & \\
\hline Light work & 152 & 31.9 & 86 & 57 & \\
\hline Heavy work & 22 & 4.6 & 14 & 64 & \\
\hline Time at this function & & & & & 0.165 \\
\hline From 03 to 12 month & 142 & 29.9 & 70 & 49 & \\
\hline From 13 to 36 months & 160 & 33.7 & 99 & 62 & \\
\hline From 37 to 60 months & 75 & 15.8 & 42 & 56 & \\
\hline From 61 to 120 months & 49 & 10.3 & 23 & 47 & \\
\hline 121 months or more & 49 & 10.3 & 25 & 51 & \\
\hline Time at this company & & & & & 0.115 \\
\hline From 03 to 12 months & 135 & 28.4 & 66 & 49 & \\
\hline From 13 to 36 months & 144 & 30.3 & 91 & 63 & \\
\hline From 37 to 60 months & 92 & 19.4 & 51 & 55 & \\
\hline $\begin{array}{l}\text { From } 61 \text { to } 120 \\
\text { months }\end{array}$ & 44 & 9.3 & 22 & 50 & \\
\hline 121 months or more & 60 & 12,6 & 29 & 48 & \\
\hline Work shift & & & & & 0.792 \\
\hline Morning & 232 & 50.8 & 128 & 55 & \\
\hline Afternoon & 170 & 37.2 & 92 & 54 & \\
\hline Evening/Night & 55 & 12.0 & 28 & 51 & \\
\hline Time worked with & & & & & \\
\hline VDT & & & & & 0.295 \\
\hline Less than 1 year & 53 & 11.1 & 29 & 55 & \\
\hline From 1 to 4 years & 259 & 54.4 & 151 & 58 & \\
\hline From 5 to 9 years & 87 & 18.3 & 43 & 49 & \\
\hline 10 years or more & 77 & 16.2 & 37 & 48 & \\
\hline
\end{tabular}

Socio-demographic characteristics, lifestyle habits and occupational history

Table 1 showed that regarding social demographic characteristics, the operators were mainly female, young and had incomplete high education level. Regarding lifestyle habits, most were non smokers and used alcohol once a week. About occupational history, the predominant time in the company and at the function was from 13 to 36 months; the time working with video display terminal (VDT) was from 1 to 4 years. Most of the operators began their work in the morning.

Table 2

Distribution of call center operators and the prevalence of CVS according to work perceptions

\begin{tabular}{|c|c|c|c|c|c|}
\hline \multirow[b]{2}{*}{ Characteristics } & \multicolumn{2}{|c|}{ Total } & \multicolumn{2}{|c|}{ Prevalence } & \multirow[t]{2}{*}{$\mathbf{p}$} \\
\hline & $N *=476$ & $\%$ & $\mathbf{N}$ & $\%$ & \\
\hline $\begin{array}{l}\text { Accoustic } \\
\text { Good } \\
\text { Regular } \\
\text { Bad }\end{array}$ & $\begin{array}{l}202 \\
151 \\
123\end{array}$ & $\begin{array}{l}42.4 \\
31.7 \\
25.8\end{array}$ & $\begin{array}{l}108 \\
80 \\
72\end{array}$ & $\begin{array}{l}53.5 \\
53.0 \\
58.5\end{array}$ & 0.596 \\
\hline $\begin{array}{l}\text { Lighting } \\
\text { Good } \\
\text { Regular } \\
\text { Bad }\end{array}$ & $\begin{array}{c}303 \\
133 \\
40\end{array}$ & $\begin{array}{c}63.7 \\
27.9 \\
8.4\end{array}$ & $\begin{array}{c}159 \\
74 \\
27\end{array}$ & $\begin{array}{l}52.5 \\
55.6 \\
67.5\end{array}$ & 0.193 \\
\hline $\begin{array}{l}\text { Temperature } \\
\text { Good } \\
\text { Regular } \\
\text { Bad }\end{array}$ & $\begin{array}{l}141 \\
175 \\
160\end{array}$ & $\begin{array}{l}29.6 \\
36.8 \\
33.6\end{array}$ & $\begin{array}{l}68 \\
98 \\
94\end{array}$ & $\begin{array}{l}48,2 \\
56,0 \\
58,8\end{array}$ & 0.169 \\
\hline $\begin{array}{l}\text { Working tools } \\
\text { Good } \\
\text { Regular } \\
\text { Bad }\end{array}$ & $\begin{array}{c}257 \\
151 \\
68\end{array}$ & $\begin{array}{l}54.0 \\
31.7 \\
14.3\end{array}$ & $\begin{array}{c}140 \\
80 \\
40\end{array}$ & $\begin{array}{l}54.5 \\
53.0 \\
58.8\end{array}$ & 0.722 \\
\hline $\begin{array}{l}\text { Space/Layout } \\
\text { Good } \\
\text { Regular } \\
\text { Bad }\end{array}$ & $\begin{array}{c}279 \\
97 \\
99\end{array}$ & $\begin{array}{l}58.7 \\
20.4 \\
20.8\end{array}$ & $\begin{array}{c}149 \\
56 \\
54\end{array}$ & $\begin{array}{l}53.4 \\
57.7 \\
54.5\end{array}$ & 0,762 \\
\hline $\begin{array}{l}\text { Chair } \\
\text { Good } \\
\text { Regular } \\
\text { Bad }\end{array}$ & $\begin{array}{l}176 \\
143 \\
157\end{array}$ & $\begin{array}{l}37.0 \\
30.0 \\
33.0\end{array}$ & $\begin{array}{l}94 \\
79 \\
87\end{array}$ & $\begin{array}{l}53.4 \\
55.2 \\
55.4\end{array}$ & 0.920 \\
\hline $\begin{array}{l}\text { Table } \\
\text { Good } \\
\text { Regular } \\
\text { Bad }\end{array}$ & $\begin{array}{c}272 \\
97 \\
107\end{array}$ & $\begin{array}{l}57.1 \\
20.4 \\
22.5\end{array}$ & $\begin{array}{c}150 \\
52 \\
58\end{array}$ & $\begin{array}{l}55.1 \\
53.6 \\
54.2\end{array}$ & \\
\hline $\begin{array}{l}\text { Number worker } \\
\text { Sufficient } \\
\text { Unsufficient } \\
\text { Unknown }\end{array}$ & $\begin{array}{c}117 \\
301 \\
57\end{array}$ & $\begin{array}{l}24.6 \\
63.4 \\
12.0\end{array}$ & $\begin{array}{c}175 \\
55 \\
30\end{array}$ & $\begin{array}{l}58.1 \\
47.0 \\
52.6\end{array}$ & 0.115 \\
\hline $\begin{array}{l}\text { Training offered } \\
\text { Sufficient } \\
\text { Unsuffficient } \\
\text { Unknown }\end{array}$ & $\begin{array}{c}313 \\
149 \\
14\end{array}$ & $\begin{array}{c}65.8 \\
31.3 \\
2.9\end{array}$ & $\begin{array}{c}90 \\
164 \\
6\end{array}$ & $\begin{array}{l}60.4 \\
52.4 \\
42.9\end{array}$ & 0.181 \\
\hline $\begin{array}{l}\text { Job satisfaction } \\
\text { Yes } \\
\text { No } \\
\end{array}$ & $\begin{array}{l}266 \\
210 \\
\end{array}$ & $\begin{array}{r}55.9 \\
44.1 \\
\end{array}$ & $\begin{array}{l}124 \\
136 \\
\end{array}$ & $\begin{array}{r}46.6 \\
64.8 \\
\end{array}$ & $<0,001$ \\
\hline
\end{tabular}

Workers' perceptions about working conditions

Table 2 shows that the operators considered the acoustic and the lighting conditions, the space/layout, the table and the quality of instruments as good. The temperature was considered regular and the chair good and bad. 
The number of existing employees in the area was considered insufficient and the training offered sufficient and job satisfaction (Table 2).

\section{Repercussions on the visual system}

The prevalence of CVS was $54.6 \%$ with 260 cases. The prevalence of ocular symptoms were: "burning" eyes 54.6\% (95\% CI, 51.6-60.6), and tearing $43.9 \%$ (95\% CI, 39.4-48.3).

The prevalence of the visual symptoms were: eye fatigue $73.9 \%(95 \% \mathrm{CI}, 69.9-77.8)$; weight in the eyes $68.2 \%(95 \% \mathrm{CI}, 64.0-72.4)$ and weakened vision 43.5 (95\% CI, 39.0-47.9).

Tables 1 and 2 show the prevalence of symptoms for each variable. The variables that were included in the logistic regression were: gender, age, alcohol intake frequency, intensity of domestic work, time working in the function, time working at that enterprise, lighting, temperature, number of workers in the area, training offered and job satisfaction.

The factor analysis resulted in the presence of four components: T1-recognition at work (lack of recognition by the company; lack of professional career; lack of autonomy at work; perception of internal environment as injustice, perceiving as being treated as machine); T2evaluation process (system of performance evaluation, ISO 9000 by the company, being monitoring by the system and supervisor), T3organization of work in call center (volume of information, multiplicity of clients, number of breaks, responsibility, queue pressure), T4work post (lack of control, inadequate tools, uncomfortable posture, computer system). Univariate regression analysis indicated association of CVS and T1 and T3 (Table 3).

Table 3 shows the association between CVS and psychosocial factors. Univariate regression analysis indicated association between CVS and work demand, decision making authority, job security and support from superiors and coworkers.

Table 4 shows the variables that remained in the final multiple regression models. It was verified associations between: being female, lack of recognition at work, organization of work in call center and high demand at work.

Table 4

Final regression model of factors associated with CVS

\begin{tabular}{lcccc}
\hline \multirow{2}{*}{ Variables } & OR & \multicolumn{2}{c}{ IC (95\%) } & \multirow{2}{*}{ P } \\
\cline { 3 - 4 } & & Inferior & Superior & \\
\hline $\begin{array}{l}\text { Gender-Female } \\
\begin{array}{l}\text { Lack of recognition } \\
\text { at work - T1 }\end{array}\end{array}$ & 2.58 & 1.62 & 4.13 & $<0.001$ \\
$\begin{array}{l}\text { Work organization in } \\
\text { call center - T3 }\end{array}$ & 1.40 & 1.14 & 1.76 & 0.002 \\
$\begin{array}{l}\text { High work demand } \\
\text { High wonn }\end{array}$ & 1.13 & 1.01 & 1.27 & 0.041 \\
\hline
\end{tabular}

Table 3

Comparison between CVS symptoms and psychosocial factors and factors of discomfort or fatigue at work

\begin{tabular}{|c|c|c|c|c|c|c|c|c|}
\hline Variável & CVS & Av. & DP & Med. & Min. & Max & $\mathbf{N}$ & $\mathbf{P}$ \\
\hline \multirow[t]{2}{*}{ Work demand } & No & 4.14 & 2.05 & 4 & 0 & 9 & 215 & \multirow[t]{2}{*}{0.001} \\
\hline & Yes & 5.03 & 1.91 & 5 & 0 & 9 & 260 & \\
\hline \multirow{2}{*}{$\begin{array}{l}\text { Decision } \\
\text { authority }\end{array}$} & No & 4.05 & 1.93 & 4 & 0 & 8 & 215 & \multirow[t]{2}{*}{$<0.001$} \\
\hline & Yes & 3.42 & 1.98 & 3 & 0 & 8 & 260 & \\
\hline \multirow{2}{*}{$\begin{array}{l}\text { Task } \\
\text { discrimination }\end{array}$} & No & 2.71 & 1.43 & 3 & 0 & 6 & 215 & \multirow{2}{*}{0.491} \\
\hline & Yes & 2.61 & 1.25 & 2,5 & 0 & 6 & 260 & \\
\hline \multirow[t]{2}{*}{ Job security } & no & 2.77 & 1.34 & 3 & 0 & 6 & 215 & \multirow[t]{2}{*}{0.023} \\
\hline & yes & 2.50 & 1.38 & 2 & 0 & 6 & 260 & \\
\hline \multirow[t]{2}{*}{ Social support } & no & 4.66 & 2.15 & 5 & 0 & 8 & 215 & \multirow[t]{2}{*}{$<0.001$} \\
\hline & yes & 3.99 & 2.00 & 4 & 0 & 8 & 260 & \\
\hline Factors & CVS & & & & & & & \\
\hline \multirow{2}{*}{$\begin{array}{l}\text { Tl-Work } \\
\text { recognition }\end{array}$} & no & -0.23 & 1.00 & & & & 203 & \multirow[t]{2}{*}{$<0.001$} \\
\hline & yes & 0.18 & 0.96 & & & & 251 & \\
\hline \multirow{2}{*}{$\begin{array}{l}\text { T2- Evaluation } \\
\text { process }\end{array}$} & no & -0.04 & 1.02 & & & & 203 & \multirow[t]{2}{*}{0.491} \\
\hline & yes & 0.03 & 0.98 & & & & 251 & \\
\hline \multirow{2}{*}{$\begin{array}{l}\text { T3-Work } \\
\text { organization }\end{array}$} & no & -0.23 & 1.03 & & & & 203 & \multirow{2}{*}{$<0.001$} \\
\hline & yes & 0.18 & 0.94 & & & & 251 & \\
\hline \multirow[t]{2}{*}{ T4- Work post } & no & -0.06 & 1.03 & & & & 203 & \multirow[t]{2}{*}{0.288} \\
\hline & yes & 0.04 & 0.97 & & & & 251 & \\
\hline
\end{tabular}

*P from T-student test; Av.: Average; Med.: Medium; Min.: Minimum; Max.: Maximum

\section{Discussion}

This study verified a high prevalence of computer visual syndrome among call centers' operators. The presence of CVS was associated with being female, lack of recognition at work, the organization of work in call centers and high demand at work.

Regarding the prevalence, Sanchez-Roman et al. [10] analyzed the frequency of asthenopia in call centers' operators in Mexico, using a questionnaire and eye examination verifying a higher prevalence: $68.5 \%$. This higher prevalence could be explained because there was an ophthalmologist evaluation. Considering the ocular symptoms the prevalence of "burning" eyes was $51.4 \%$ and tearing was $37.1 \%$ similar that obtained in this study.

In India, Bhanderi et al. [6] analyzing 419 operators who worked using the computer found a prevalence of $46.3 \%$ of asthenopia. This result can be explained because they used the computer but they were not call centers' operators that remained sit in front of the terminal during all journey.

The association observed between the presence of CVS and being female was also observed by Rocha and Debert-Ribeiro [12] that studied the systems analysts and visual fatigue. 
In this study we did not observe association between CVS and environmental conditions that could be explained because the call centers' operators considered the lighting as good. On the contrary, Raab Glina and Rocha [7], while studying call centers' operators at a bank in Sao Paulo, found complaints about the lighting that was weak at night.

The lack of recognition at work which was observed in this study as associated with CVS included the lack of professional career and autonomy at work and the perception to being treated as a machine.

In this study we verified that the activity of operators in call centers involves high mental work demands (cognitive and emotional) with low autonomy. Considering the demand-control model by Karasek and Theorell [22], we can describe the call center operator activity as a high strain job. This result was also observed by Toomingas et al. [1] in Swedish call centers.

The association observed between CVS and the lack of control was also studied by Vilela and Assunção [15] that detailed the mechanisms of control used by a call center of an enterprise of telephony demonstrating the intense control of their work. They had the control of the time of each call, the words that had to be used (script), the time that they were in pauses, the volume and the results at work.

Regarding the perception of being treated as a machine, it was also observed by Sznelwar and Massetti [14] that studied call centers' operators in a financial enterprise and described that even though they spent all the time communicating with customers, they felt that in many situations, they are using the vocal tract and brain but the standardizations established by the organizers of the work generated the complaint of being "seen or treated" like a machine.

In the study we observed an association between CVS and how is the organization of work in call center with high volume of information, variety of demands from clients with different cultures, small number of breaks and high responsibility.

Rocha et al. [13] explained that call center operators activity integrates the computer work hazards to risk related to the telephone operator's work. Computer work's hazard like static posture as a consequence of the characteristic of the workstation which required constant sitting posture, with the vision directed to the screen and the attention distributed between the screen and headset; inadequate furniture and repetitive motions. The risks associate with telephone operators were: an extreme prescription of work, the call time pressure associated to the monitoring of the quality of customer service, routine work, low job control and the presence of psycho affective demands related to the interaction with the customers.

One important factor was the "pressure of the queue" factor represented by the number of customers waiting to be served also observed by Raab Glina and Rocha [7].

Another characteristic of work organization in call center activity observed by Fernandes et al. [23]: the existence of "bonus" awards for individual productivity resulting in a competitive job.

In this study we observed an association between CVS and high demand among call centers' operators work. This results are similar with Sanchez-Roman et al. [10] that described that asthenopia was associated with working more than four hours in front of the video terminal. Ghassemi-Broumand and Ayatollah [16] also verified more ophthalmic complications between workers that use computer for more than 4 hours.

This study highlights the need for action to change work environment conditions and work organization, to analyze professional activity at call centers and at the same time, of workers characteristics. For Costa and Kara-Jose [19], the promotion of eye health is necessary to ensure a good quality of life: the individual must have visual ability that allows the development of their capabilities and their participation in society.

According to the Committee of the International Commission of Health, the current way of dealing with the issues of "work and vision" is still isolated, for example, eye exams performed by ophthalmologists, lighting designed by engineers and architects, chemical pollution studied by occupational hygienists. Because of the complexity of the relationship about work and vision, these actions are limited and ineffective in protecting workers' health.

Regarding the legislation to prevent CVS, the European Economic Community (EEC), through its Council, published on May 29, 1990 the Directive No. 90/270/EEC about health and safety related to VDT (video display terminal) work that includes preliminary ergonomic assessment of workplace by the employer and eye exam before starting work and tests performed periodically.

In England, the Ministry of Work through the Health \& Safety Executive/Local Authorities Enforcement Liaison Committee (HELA), published a recommendation (Advice Regarding Call Centre Working Practices) in December 2001, including the following aspects about the visual health of the operators: regulation of contrasting screen; breaks for visual rest and regular eye exams.

In Brazil, only in March 2007, The Ministry of Work and Employ published an Ergonomic 
Guideline to call center activity that indicates ergonomic work analysis to better define the performance of the tasks and prevention of visual symptoms [4].

In this study, ergonomic work analysis was important to construct the questionnaire about the relation between work and health. The factors related with work organization were identified by this ergonomic analysis.

The main limitation of this study was that it was a cross-sectional epidemiological design, not allowing inferences of causality. In addition, this study involved only two call centers, not including workers who were removed for reasons of health. This study did not include the eye exams of the operators. On the other hand, this research adds to the literature data about specific factors associated with visual symptoms among call centers' operators.

\section{Conclusions}

The results demonstrated the importance of studying the CVS among call centers' operators and that there is an association between the symptoms and working conditions. The program of prevention of CVS should include eye examination periodically among the call centers' operators and the design of the work should take account psychosocial and organizational factors.

\section{References}

[1] A. Toomingas, et al., Working conditions and employee health at call centers in Sweden, National Institute for Working Life, Stockholm, 2002.

[2] B. Piccoli, A critical appraisal of current knowledge and future directions of ergophthalmology: consensus document of the [4] ICOH Committee on "Work and Vision", Ergonomics 46 (2003), 384-406.

[3] B.B. Read, Ergonomics: RX for call centers, Call Center Magazine, 14 (2001), 54-66.

[4] Brasil. Ministério do Trabalho. Normas Regulamentadoras (NR). 2007. Disponível em: http:/www.mte.gov.br/legislacao/normas regulament adoras/nr_17_anexo2.pdf

[5] C. Blehm, S. Vishnu, A. Khattak, S. Mitra and R.W. Yee, Computer vision syndrome: a review, Survey Ophthalmology 50 (2005), 253-262.

[6] D.J. Bhanderi, S. Choudhary and V.G. Doshi, A community-based study of asthenopia in computer operators, Indian J Ophthalmol, 56 (2008), 51-55.

[7] D.M. Raab Glina and L.E. Rocha, Psychosocial aspects of work of female call center operators in a bank of São Paulo, Brazil, Psykhe 11 (2002), 109-20.

[8] E. Brevigliero, J. Possebon and R. Spinelli, Higiene ocupacional. Agentes biológiocos, químicos e físicos, $3^{\mathrm{a}}$ ed., Ed. SENAC, São Paulo, 2006.

[9] F Guérin, A Laville, F Daniellou, J Duraffourg, A Kerguelen, Comprende le travail pour le trabsformer: la pratique de I!ergonomie, Ed. ANACT, Montrouge, 1991.

[10] F.R. Sanchez-Román, C. Pérez-Lucio, C. JuárezRuiz, N.M. Vélez-Zamora and M. Jiménez-Villarruel, Factores de risco para la astenopía em operadores de terminales de computadoras, Salud Pública de México 38 (1996), 189-196.
[11] ILO - International Labour Organization, 1986. Disponível em: http://www.ilo.org

[12] L.E. Rocha and M. Debert-Ribeiro, Working conditions, visual fatigue, and mental health among systems analysts in São Paulo, Brazil, Occupational Environmental Medicine 61 (2004), 24-32.

[13] L.E. Rocha, D.M.R. Glina, M.F. Marinho and D. Nakasato, Risk factors for musculoskeletal symptoms among Call Center Operators of a bank in São Paulo, Brazil, Industrial Health 43 (2005), 637-646.

[14] L.I. Sznelwar and M. Massetti, Sofrimento no trabalho: uma leitura a partir de grupos de expressão, in: $\mathrm{O}$ trabalho humano com sistemas informatizados no setor de serviços, L.I. Sznelwar and L.N. Zidan, org., Editora Plêiade, São Paulo, 2000, pp. 105-117.

[15] L.V.O. Vilela and A.A. Assunção, Os mecanismos de controle da atividade no setor de teleatendimento e as queixas de cansaço e esgotamento dos trabalhadores, Caderno Saúde Pública, 20 (2004), 1069-1078.

[16] M. Ghassemi-Broumand and M. Ayatollahi, Evaluation of frequency of complications of working with computers in a group of young adult computers users, Pak J Med Sci, 24 (2008), 702-706.

[17] M. Ziefle, Effects of display resolution on visual performance, Human Factors, 40 (1998), 554-568.

[18] M.C. Acosta, J. Gallar and C. Belmonte C, The influence of eye solutions on blinking and ocular comfort at rest and during work at vídeo display terminals, Experience Eye Research 68 (1999), 663669.

[19] M.N. Costa and N. Kara-Jose, Oftalmologia para o clínico, Cultura Médica, Rio de Janeiro, 2008, pp. 217.

[20] P.H. Travers and B.A. Stanton, Office workers and video display terminals: physical, psychological and ergonomic factors, AAOHN J 50 (2002), 489-493.

[21] R. Elias and Cail F, Contraintes et astreintes devant les terminaux a ecran cathodique, Institut National de Recherche et de Sécurité, Paris, 1982. (Reproduction du texte du rapport no. 1109/RE, v.43).

[22] R.A. Karasek and T. Theorell, The environment, the worker, and illness: psychosocial and physiological linkages, in: Health work: stress, productivity and the reconstruction of working life, R.A. Karasek and T. Theorell, Basic Books, New York, 1990.

[23] S. Fernandes, et al., Organização e Condições de Trabalho em telemarketing: Repercussões na Saúde Psíquica dos Trabalhadores, in: Saúde Mental e Trabalho - Leituras, M. Jacques and W. Codo, org. Vozes, Petrópolis, 2002, pp. 247-270.

[24] T.M. Araújo, Uso do Job Content Questionnaire na avaliação dos aspectos psicossociais do trabalho e saúde mental: resultados de um estudo com professores, in: Saúde mental no trabalho: da teoria à prática, D.M.R. Glina and L.E. Rocha, org., Roca, São Paulo, 2010, pp.139-159.

[25] Z. Ye, S. Honda, Y. Abe, Y. Kusano, N. Takamura, Y. Imamura, K. Eida, T. Takemoto qn K. Aoyagi, Influence of work duration or physical symptoms on mental health among japanese visual display terminal users, Industrial Health 45 (2007a), 328-333.

[26] Z. Ye, Y. Abe, Y. Kusano, N. Takamura, K. Eida, T. Takemoto and K. Aoyagi, The influence of visual display terminal use on the physical and mental conditions of administrative staff in Japan, Journal Physiology Anthropology 26 (2007b), 69-73. 